\title{
A Review and Analysis of Factual Change on the Max Rise of the Swedish Scandes Treeline, in Relation to Climate Change over the Past 100 Years
}

\section{Kulliman L* \\ Dept. Ecology \& Environmental Science, Umeå University, Sweden}

*Corresponding author: Prof Leif Kullman, Dept. Ecology \& Environmental Science, Umeå University, 90187 Umeå, Sweden, Tel: +46705641848; Email: leif.kullman@umu.se

\section{Research article}

Volume 2 Issue 6

Received Date: November 13, 2018

Published Date: November 23, 2018

DOI: $10.23880 /$ jenr-16000150

\section{Abstract}

Treeline advance during the past 100 years was assessed by repeat in situ measurement at 14 locations distributed along the Swedish Scandes, c. $800 \mathrm{~km}$ from south to north. Concerned species were mountain birch (Betula pubescens ssp. czerepanovii), Norway spruce (Picea abies), Scots pine (Pinus sylvestris) and rowan (Sorbus aucuparia). Treeline was narrowly defined as the highest elevation with trees, at least $2 \mathrm{~m}$ tall. In order to elucidate the full effect and power of climate change on the treeline area, focus was on sites with the most extensive treeline shifts along the entire Swedish Scandes, according to prior regional surveys. Thereby, local constraints (topoclimate) were minimized. Betula and Picea accomplished treeline rise predominantly by phenotypic height growth increment of old-established krummholz, while Pinus responded by establishment and growth of new specimens. The largest upshifts along the entire Scandes and irrespective of species were in the order of $200 \mathrm{~m}$ (max. $245 \mathrm{~m}$ ). In perspective of historical treeline shifts, the new and higher treelines are close to the position prevailing about 7000 years ago. In contrast to previous generalizations, no obvious differences existed between southern and northern Scandes. Based on a common temperature lapse rate of 0.6 ${ }^{\circ} \mathrm{C}$ per $100 \mathrm{~m}$ altitude and recorded regional and centennial summer warming of $1.6^{\circ} \mathrm{C}$, the observed rise appears as a fully expected response. This kind of performance indicates that, at optimal sites, treelines are in equilibrium with climate at a centennial scale, in cases of climate warming.

Keywords: Treeline Shift; Climate Change; Swedish Scandes; Regeneration Modes; Betula pubescens ssp. czerepanovii; Picea abies; Pinus sylvestris; Sorbus aucuparia 


\section{Journal of Ecology \& Natural Resources}

\section{Introduction}

There is increasing evidence that elevational treelines are robust and important climate change indicators [1] Based on empirical/observed data, complemented with eco-physiological understanding it appears that, with respect to elevation, cold-marginal treelines respond sensitively to altered climatic conditions during both summer and winter at a global and centennial scale. Locally and regionally they are modulated by site factors such as topography, soil conditions and herbivory [2-41].

Also at longer, Holocene time-scales does Scandinavian treeline history express a strong association with low-frequency thermal trends, principally driven by insolation forcing at the top of the atmosphere [42]. Treeline descent by 600-700 $\mathrm{m}$ during the past 9000-10 000 years in widely different parts of the Swedish Scandes, represents an overall cooling by about $3^{\circ} \mathrm{C}$, adjusted for land uplift $[43,44]$. A substantial break in this trend, by the early-20th century until the present day, raised ambient summer air temperature by about $1.6^{\circ} \mathrm{C}$, with substantial impact on treelines, glaciers and alpine plant cover $[28,8,9,17,45]$.

A major problem with dynamic treeline change research is the bewildering of terms and definitions [4648]. First, a distinction is needed to be made between the "forest limit", i.e. the upper closed forest and the "treeline", i.e. the upper limit of solitary trees. In most cases they run in parallel along a specific mountain slope, with an average difference of about $55 \mathrm{~m}$ [49]. From a functional point of view, however, they may differ with respect to responsiveness to climate change and variability $[50,13,50]$. The "treeline", as a rule prevailing in a more or less open low alpine landscape or in a matrix of sparse tree stands of the same or other tree species, bears a relatively more direct relationship to prevailing climatic conditions. The "forest limit", on the other hand, creates by the density of stems a more sheltered habitat, with complex inter- and intraspecific interactions, both positive and negative. As a consequence, forest limit responses to altered climatic conditions tend to be relatively more subdued and delayed $[13,14,18,50])$. With a broader landscape-ecological view, the term "treeline ecotone" may be an appropriate subject for scientific study. This concept refers to the entire plant cover within the elevational interval between the uppermost closed forest and the alpine tundra, where forest disintegrates into isolated tree individuals. It defines a complex and mostly climate-related transition zone with its own structural, compositional and dynamic characteristics [47,9,51-54].

Henceforth in this paper, a very precise treeline definition is used, stating that the treeline is the elevation ( $\mathrm{m}$ a.s.l.) of the uppermost individual of any concerned species, which is at least $2 \mathrm{~m}$ tall. By complying with this definition, which is relatively easily documented in the field, there is little room for subjective judgement.

From the perspective of monitoring climate change impact on alpine/subalpine vegetation and landscape, the treeline, as narrowly defined above, should be preferred as it provides the most straightforward response to climate change and variability [13,11]. Stands with solitary and sparsely distributed trees are supposed to display a higher sensitivity to climate variations than the closed forest $[55,56]$.

Moreover, by focusing on the uppermost solitary tree, often in a more or less inaccessible terrain, the impact of man and animals is minimized, according to the "Principle of Least Effort" [57,58]. Thus, fair and reproducible comparisons, with climate change ambitions, can be made both in time and space. Moreover, a usable testament to the future is saved [12].

Some earlier studies, based on Betula pubescens ssp. czerepanovii, have questioned that modern treeline rise is a common pattern for the entire Swedish Scandes [59,60]. Here, this aspect assessed for different tree species and with an accurate treeline definition.

Based on studies referred to above and assuming a treeline-temperature equilibrium coupled with an adiabatic temperature lapse rate of $0.6{ }^{\circ} \mathrm{C}$ per $100 \mathrm{~m}$ elevation [61] and recorded temperature rise by 1.6 and $1.4{ }^{\circ} \mathrm{C}$ (1901-2015) for summer and winter, respectively, along the Swedish Scandes $[17,18]$ (Figure 1). In the case of summer temperatures, the largest and most consistent warming was during the period 1900 to 1940 . Thereafter, the trend seems quite indistinct, although remaining at fairly high level, with large inter-annual variability. The warming of the winter temperatures is more consistent, although not statistically significant, with the rise peaking during the past few decades. Considering the time it takes for a tree to reach mature size, we predict a common treeline rise of about $200-250 \mathrm{~m}$ to be realized over the past century at the most optimal types of sites.

Assessment of treeline rise since about 1915 and until 2015/17 was carried out for different common tree species at sites distributed along the entire extension of 


\section{Journal of Ecology \& Natural Resources}

the Swedish Scandes, from south to north. Some of these histories have been narrated in previously published studies $[28,17,62]$. Here a comprehensive overview and update are presented. Particularly the largest upshifts, i.e. about $200 \mathrm{~m}$, are focused as these should be relatively little affected by confounding local abiotic and biotic site factors, which may constrain climate-induced treeline shift and hide the expression of the full extent and power of climate change. Thereby the above-mentioned prediction can be tested.
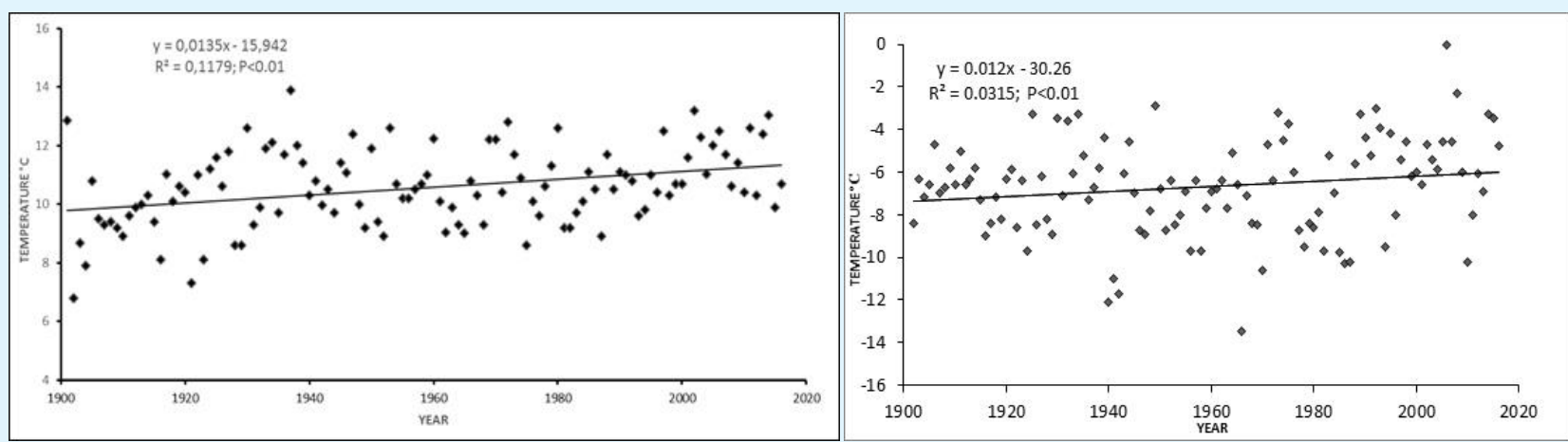

Figure 1: Annual mean temperatures for the period June-August 1901-1916 (left) and for the period December-

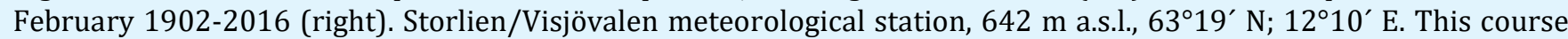
of change is broadly representative for the entire Swedish Scandes [17].

\section{The common structure and composition of the treeline ecotone in the Swedish Scandes}

A comprehensive overview of the plant cover structure of the treeline ecotone is provided by Kullman $[9,53]$. As a rule, mountain birch (Betula pubescens Ehrh. ssp. czerepanovii [Orlova] Hämet - Ahti) forms the upper tree- and forest belts, adjacent to the alpine tundra. The understorey vegetation is commonly dwarf shrub heath (e.g. Vaccinium myrtillus, Empetrum hermaphroditum, Betula nana and Phyllodoce caerulea), complemented with some low herbs and mosses. In tracts with poor soils and a local continental climate, Calluna vulgaris and reindeer lichen heaths (Cladonia spp.) prevail in the treeline ecotone. In general, the treeline of all species is formed by more or less stunted solitary trees or small copses.

The mountain birch forest belt depends on sustained melt-water supply throughout the summer, from slowly melting snow patches at higher elevations. In addition, the structure and composition of the ground cover relates to soil fertility and snow cover distribution/endurance.

The treelines of Norway spruce (Picea abies L.) Karst. and Scots pine (Pinus sylvestris L.) are, as a rule, positioned about 60 and $115 \mathrm{~m}$ below that of the mountain birch. This implies that they both prevail within a more or less closed forest matrix, mostly in glades and openings, where competition for light and other resources is limited [49].

Common natural disturbances to the tree- and ground cover are grazing/trampling by semi-domesticated reindeer [63], and in the case of Betula, defoliating outbreaks by caterpillars of the Autumnal moth (Epirrita autumnata) $[64,65]$. As a rule, in these respects, there is a trade-off between negative and positive impacts as far as the treeline proper is concerned separated from the treeline ecotone in general [17].

\section{Methods}

Elevational treeline shift of different tree species over the past 100 years or so was assessed by in situ measurement during the past 10 years of treeline position at 14 localities, distributed along the Swedish Scandes, about $800 \mathrm{~km}$ from south to north (Figure 2). Data of past and present treeline positions originate from published papers, presented in association with each case. The main focus is on the treeline position, based on historic and recent observations.

Past treeline elevations (1915-1975), have been assessed with a Paulin aneroid barometer, while more recent records are based on a GPS receiver (Garmin 60 CS), repeatedly calibrated against modern topographical 
maps. In most cases, the accuracy is judged to be within the interval $\pm 5 \mathrm{~m}$.

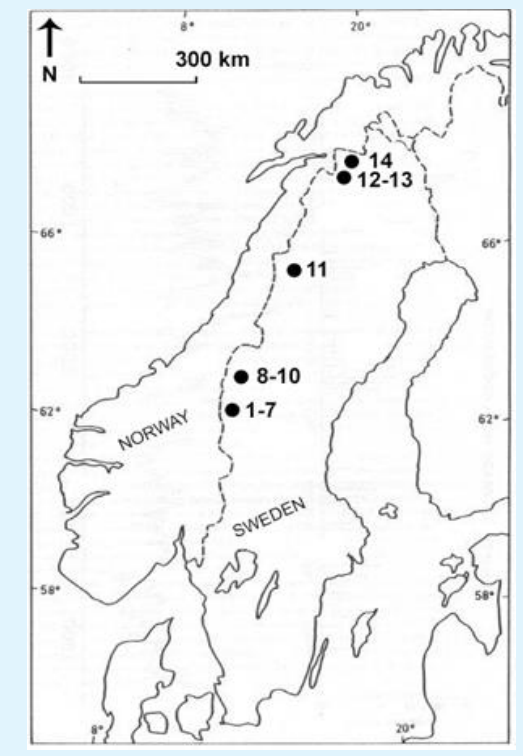

Figure 2: Location of study sites along the Swedish Scandes. Numbers refer to site histories (see Results).
Treeline positions by the early 20th century are obtained from published records, foremost [66,67]. These older data have been checked for accuracy by coring trees $2 \mathrm{~m}$ above the ground level. Recent change is assessed by dendroecological analyses within vertical belt transects running between the present-day treeline position and its elevation by the early 20th century, as estimated from published older records, complemented and verified by coring stems $2 \mathrm{~m}$ above the ground level. These endeavours are carried out in belt transects, with a width of 200-500 m, running perpendicular to the slope contours and upslope from the reported/ reconstructed treeline positions by the early $20^{\text {th }}$ century.

\section{Results}

\section{Individual site histories}

Below, 14 cases (sites), representing different species, display upslope treeline shift by about $200 \mathrm{~m}$ during the last 100 years (Figure 2). The investigated sites and their "treeline markers" are presented with current (20072018) photographs and relevant metadata.

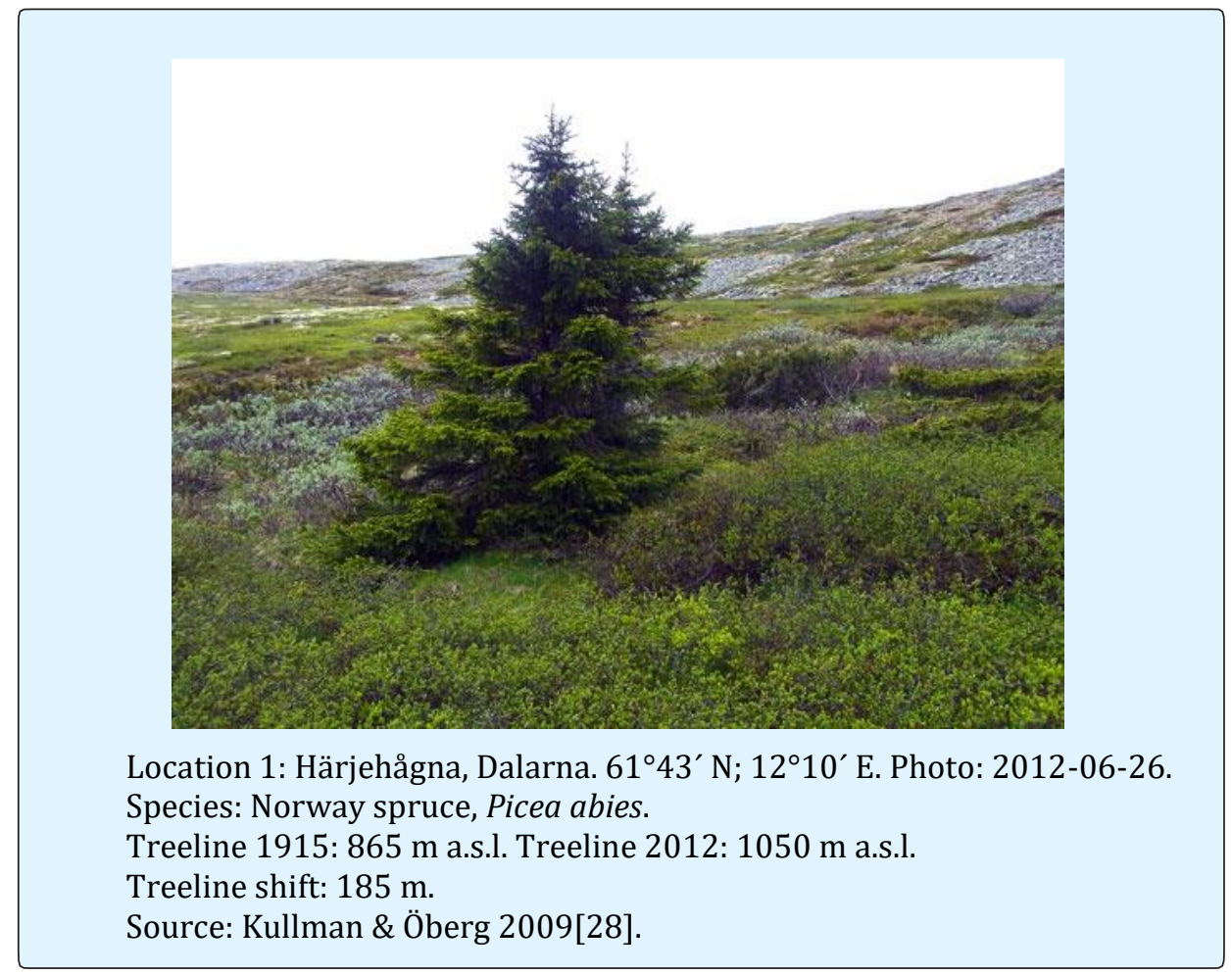

Kullman L. A Review and Analysis of Factual Change on the Max Rise of the 


\section{Journal of Ecology \& Natural Resources}
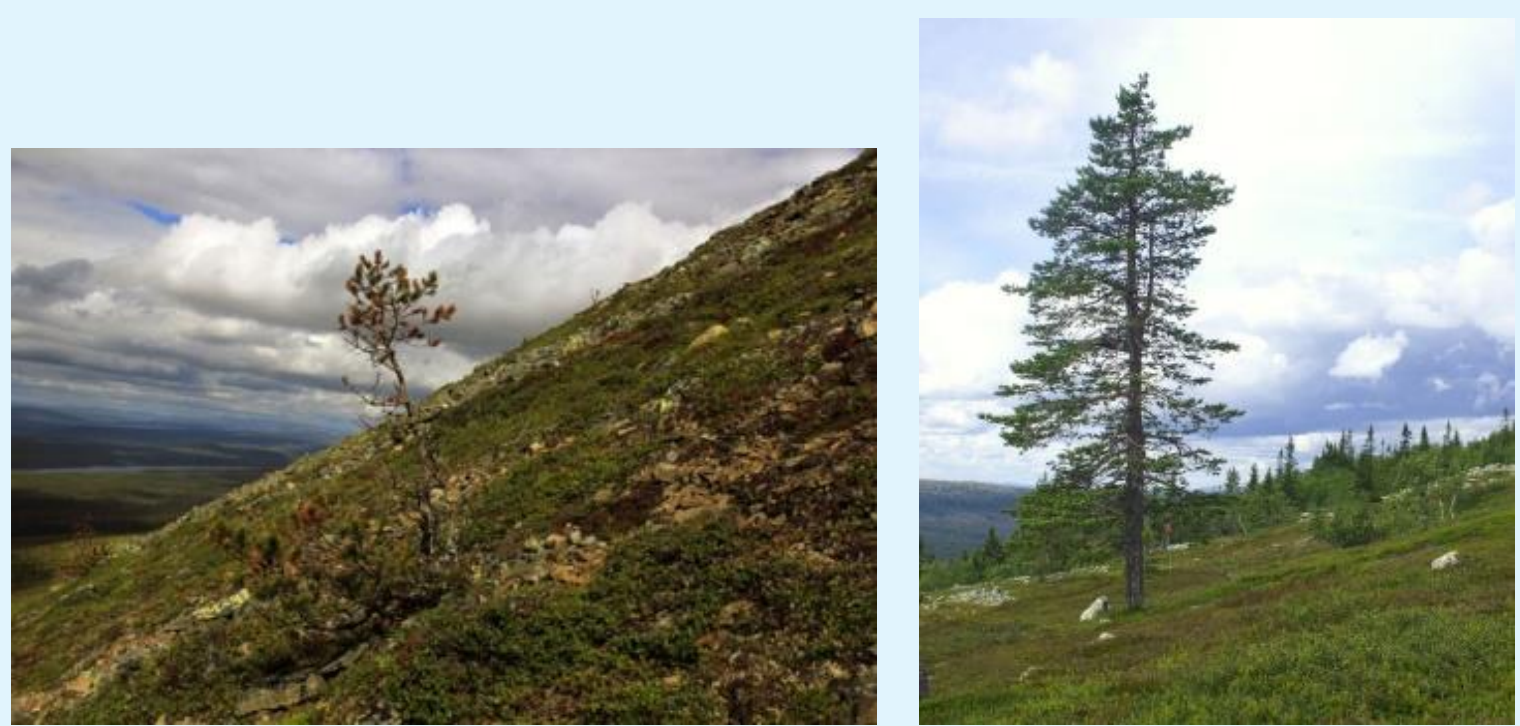

Location 2: Städjan, Dalarna. $61^{\circ} 54^{\prime} \mathrm{N} ; 1^{\circ} 52^{\prime}$. E. Left. Photo: 2013-06-24. Right. Tree representing the treeline by the early $20^{\text {th }}$ century. Photo: 2007-07-14.

Species: Scots pine, Pinus sylvestris.

Treeline 1915: 865 m a.s.l. Treeline 2013: 1045 m a.s.l.

Treeline shift: $180 \mathrm{~m}$.

Source: Kullman \& Öberg 2009 [28]; Kullman 2015c [12].
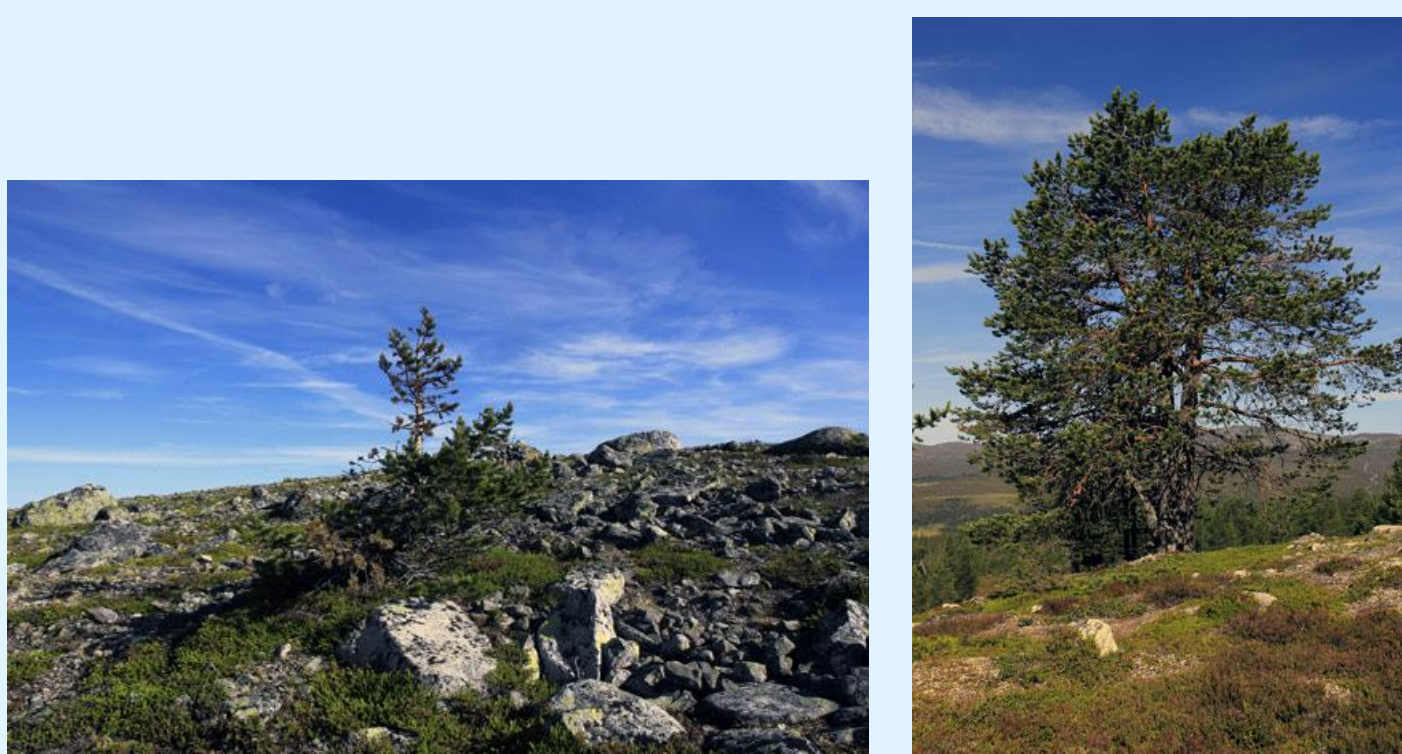

Location 3: Blåkläppen, Dalarna. $62^{\circ} 05^{\prime} \mathrm{N} ; 1^{\circ} 21^{\prime}$ E. Left. Photo: 2013-07-24. Right. Tree representing the treeline by the early $20^{\text {th }}$ century. Photo: 2013-07-24.

Species: Scots pine, Pinus sylvestris.

Treeline 1915: 845 m a.s.l. Treeline 2013: 1020 m a.s.l.

Treeline shift. $175 \mathrm{~m}$.

Source: Kullman 2017a [17]. 


\section{Journal of Ecology \& Natural Resources}
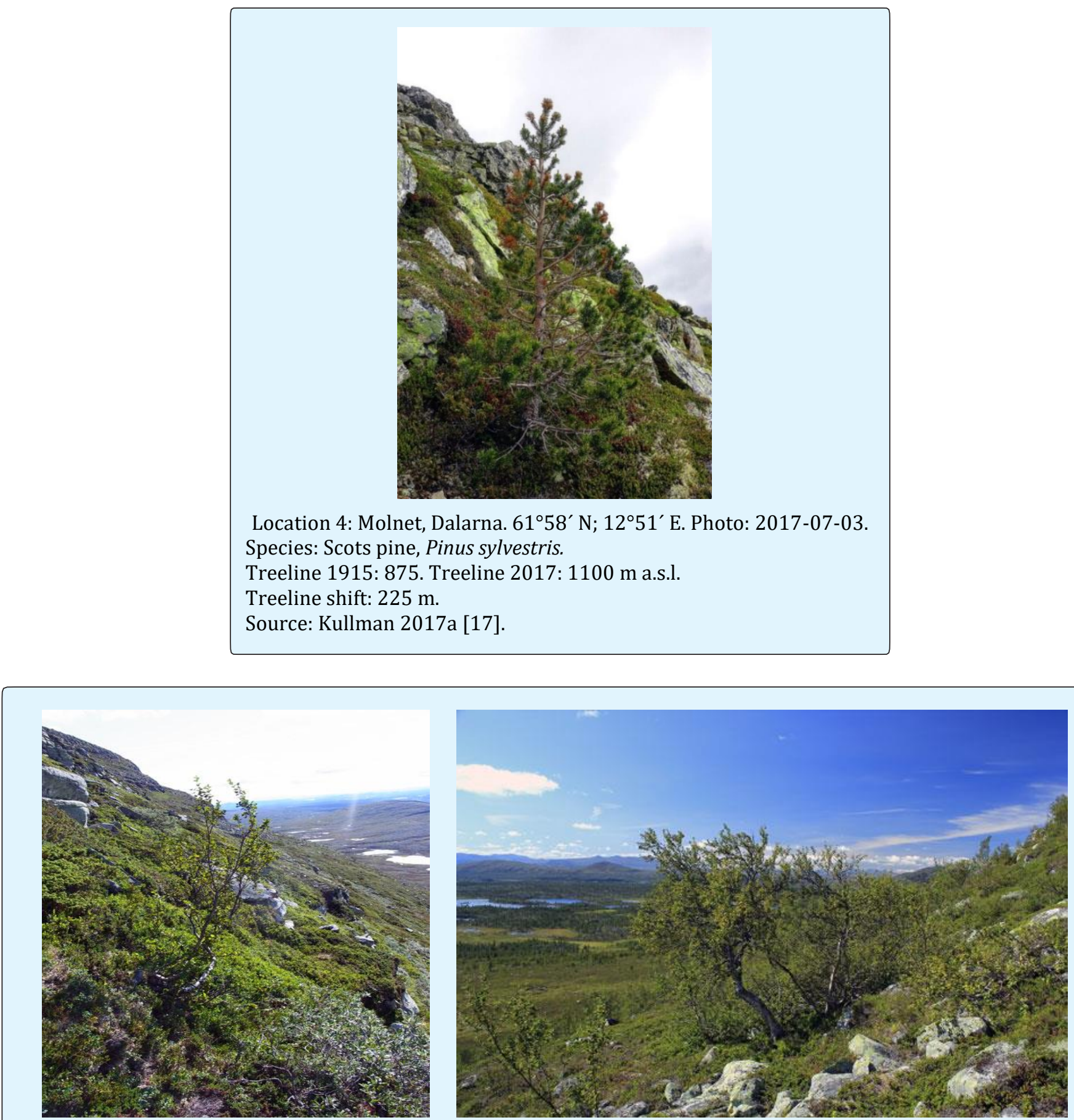

Location 5: Brattriet, Härjedalen. $62^{\circ} 25^{\prime} \mathrm{N} ; 1^{\circ} 2^{2} 3^{\prime} \mathrm{E}$. Left. Photo: 2011-08-12. Right. Tree representing the treeline position by the early $20^{\text {th }}$ century. Photo: 2011-08-12.

Species: Mountain birch, Betula pubescens ssp. czerepanovii.

Treeline 1915: 945 m ö.h. Treeline 2011: 1140 m a.s.l.

Treeline shift: $195 \mathrm{~m}$.

Source: Öberg \& Kullman 2012 [62]. 


\section{Journal of Ecology \& Natural Resources}
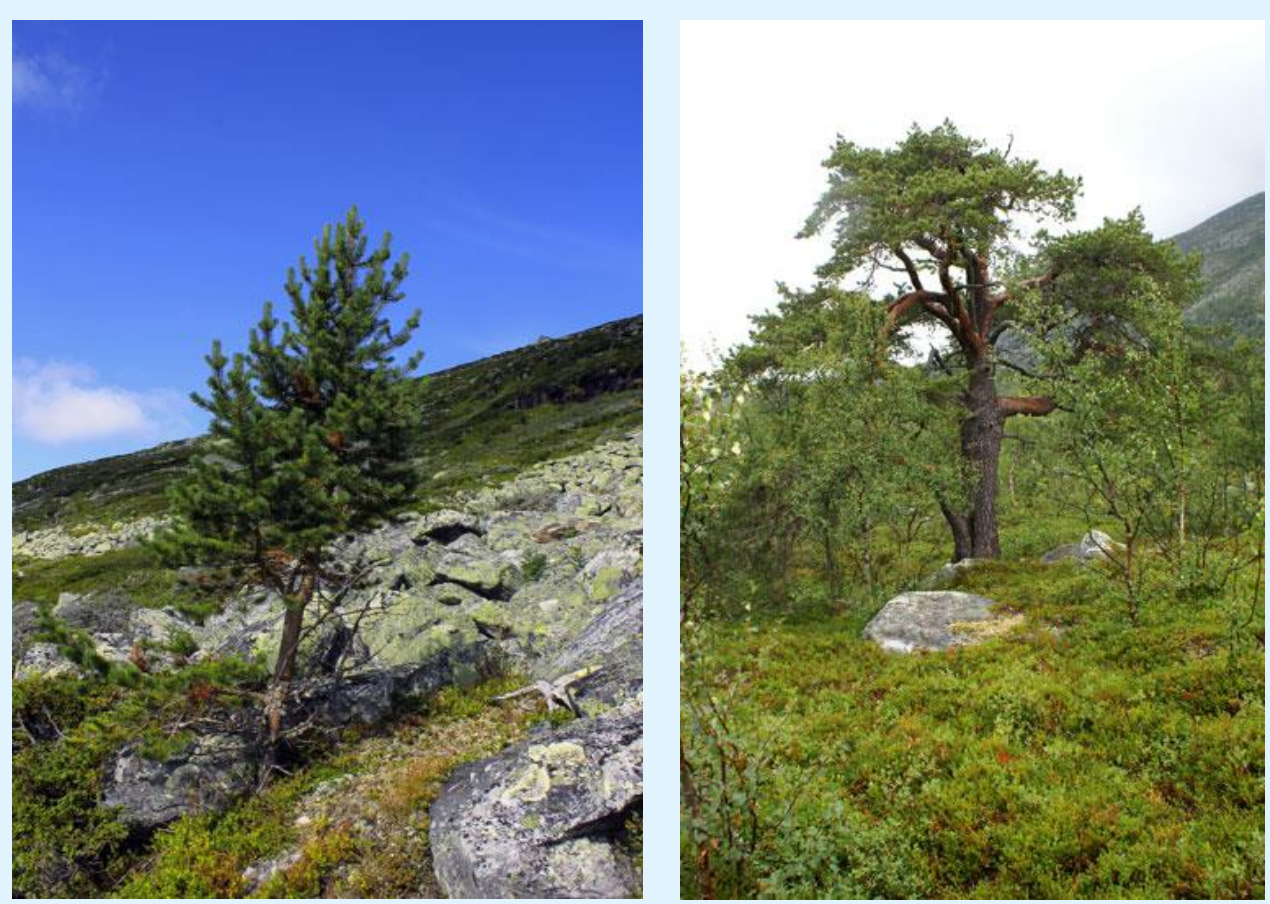

Location 6: Brattriet, Härjedalen. $62^{\circ} 25^{\prime} \mathrm{N} ; 1^{\circ} 23^{\prime}$ E. Left. Photo: 2011-08-12. Right. Tree representing the treeline position by the early $20^{\text {th }}$ century. Photo: $2006-08-23$.

Species: Scots pine, Pinus sylvestris.

Treeline 1915: 920 m a.s.l. Treeline 2011: 1075 m a.s.l.

Treeline shift: $155 \mathrm{~m}$.

Source: Öberg \& Kullman 2012 [62].

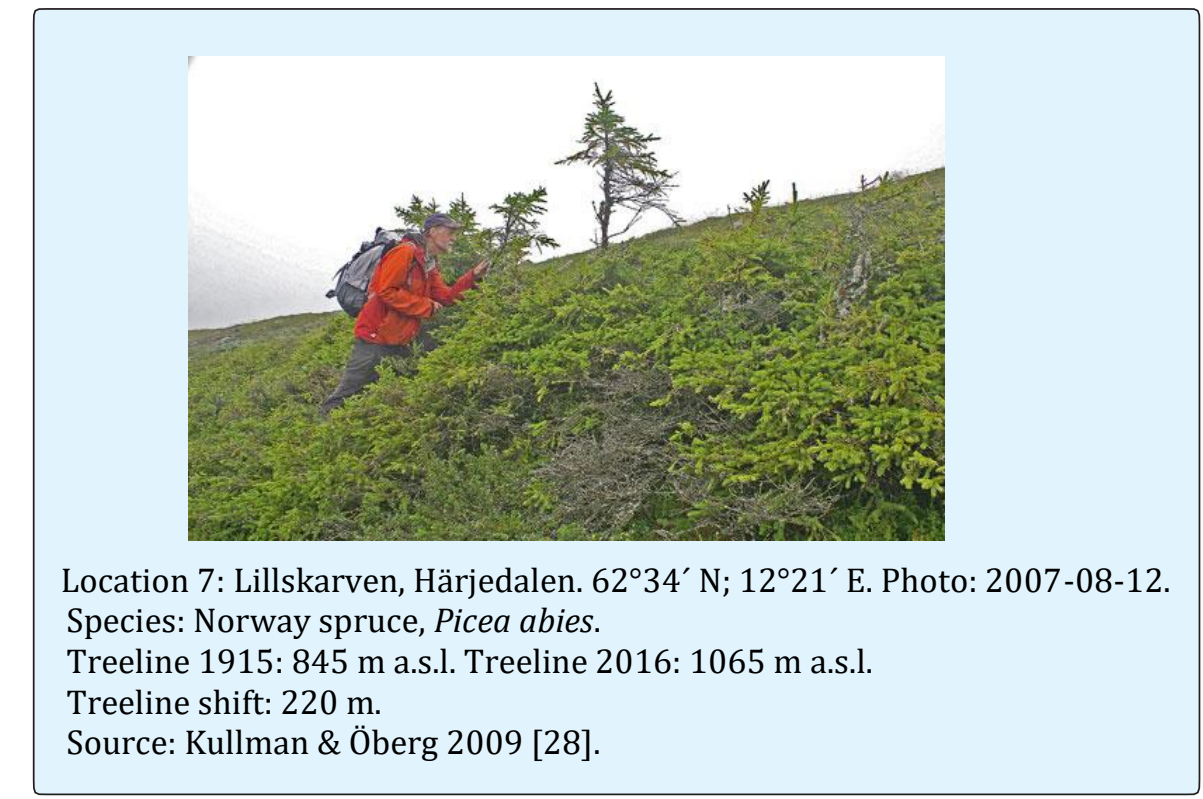

Kullman L. A Review and Analysis of Factual Change on the Max Rise of the 


\section{Journal of Ecology \& Natural Resources}
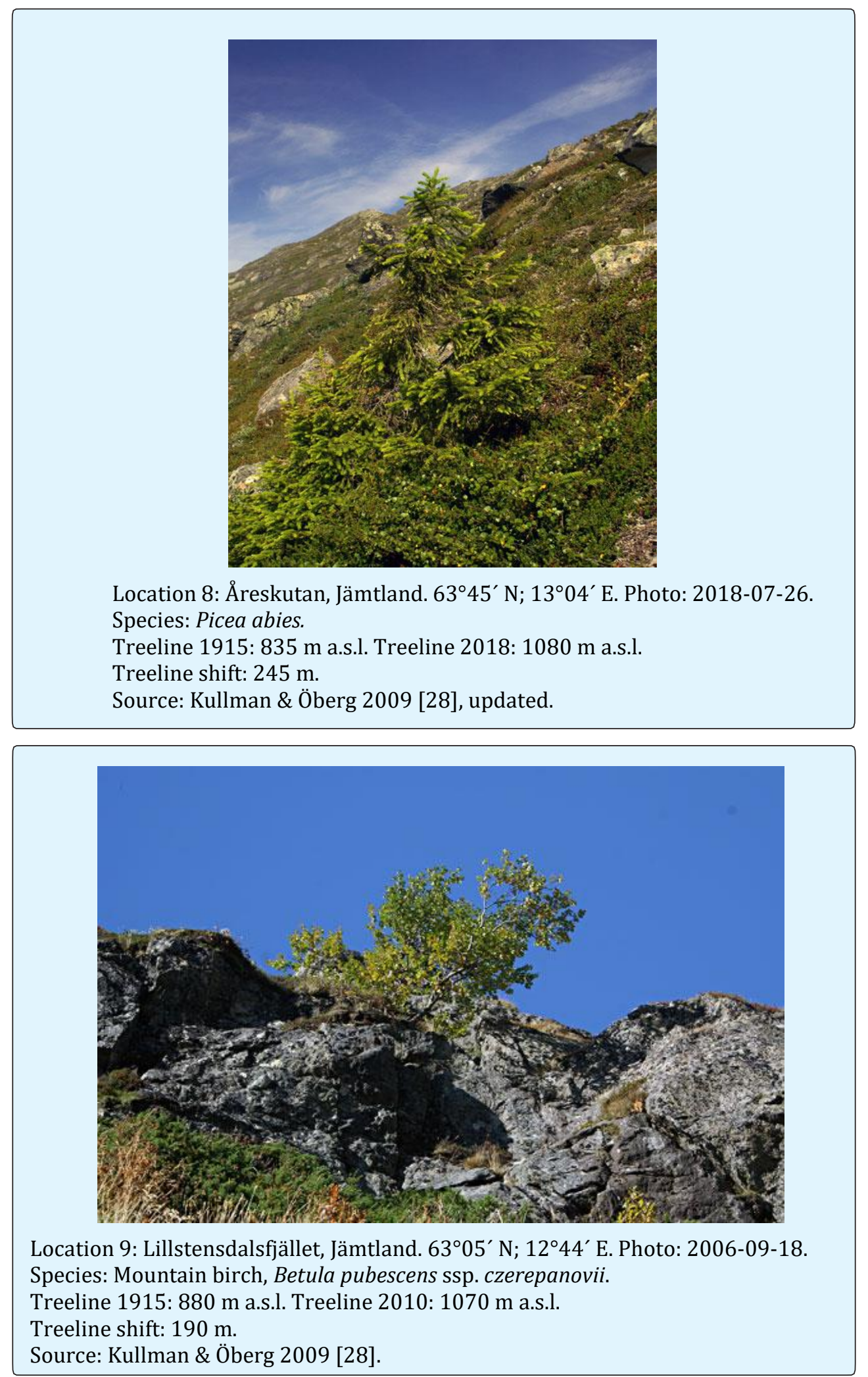

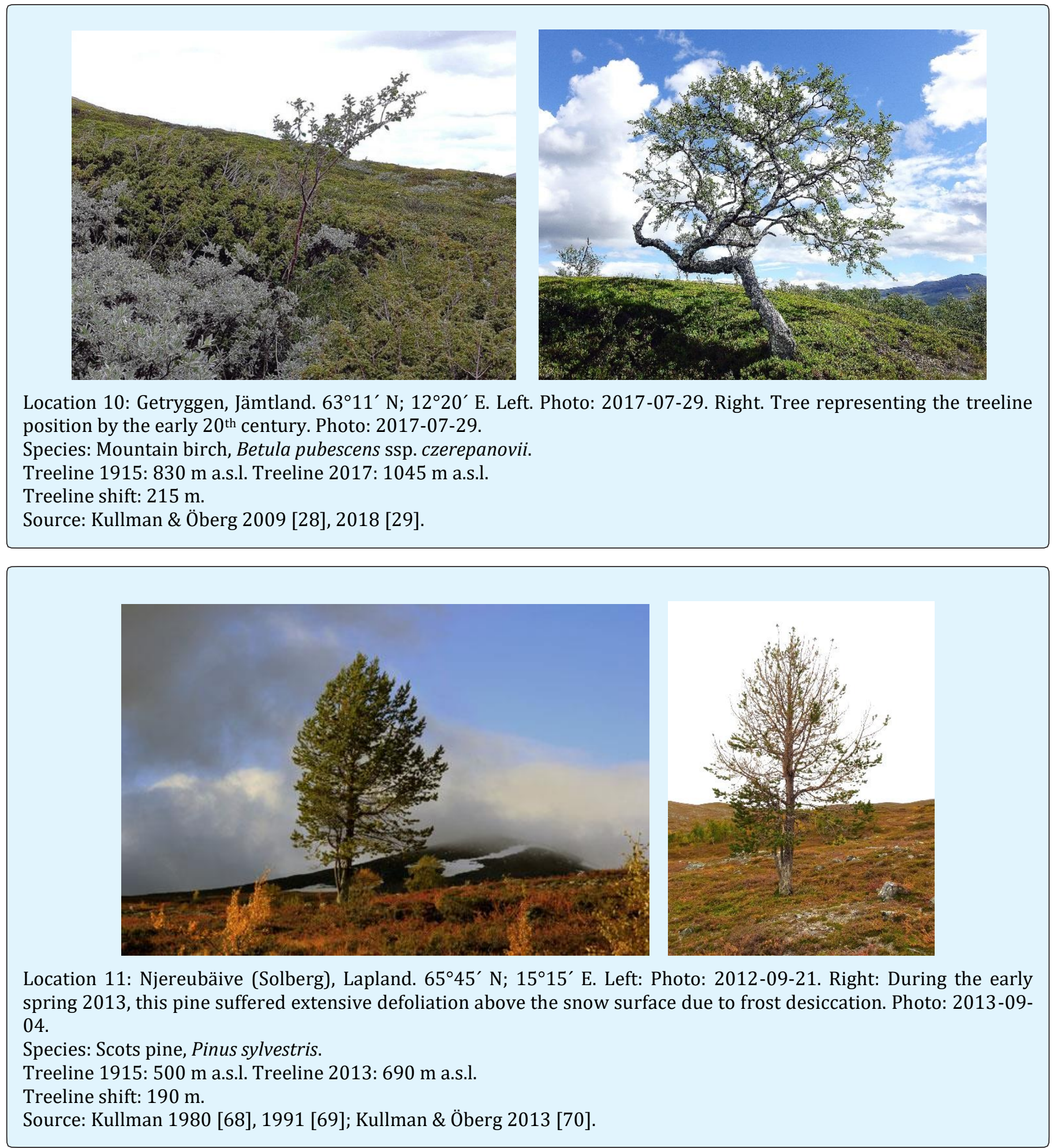

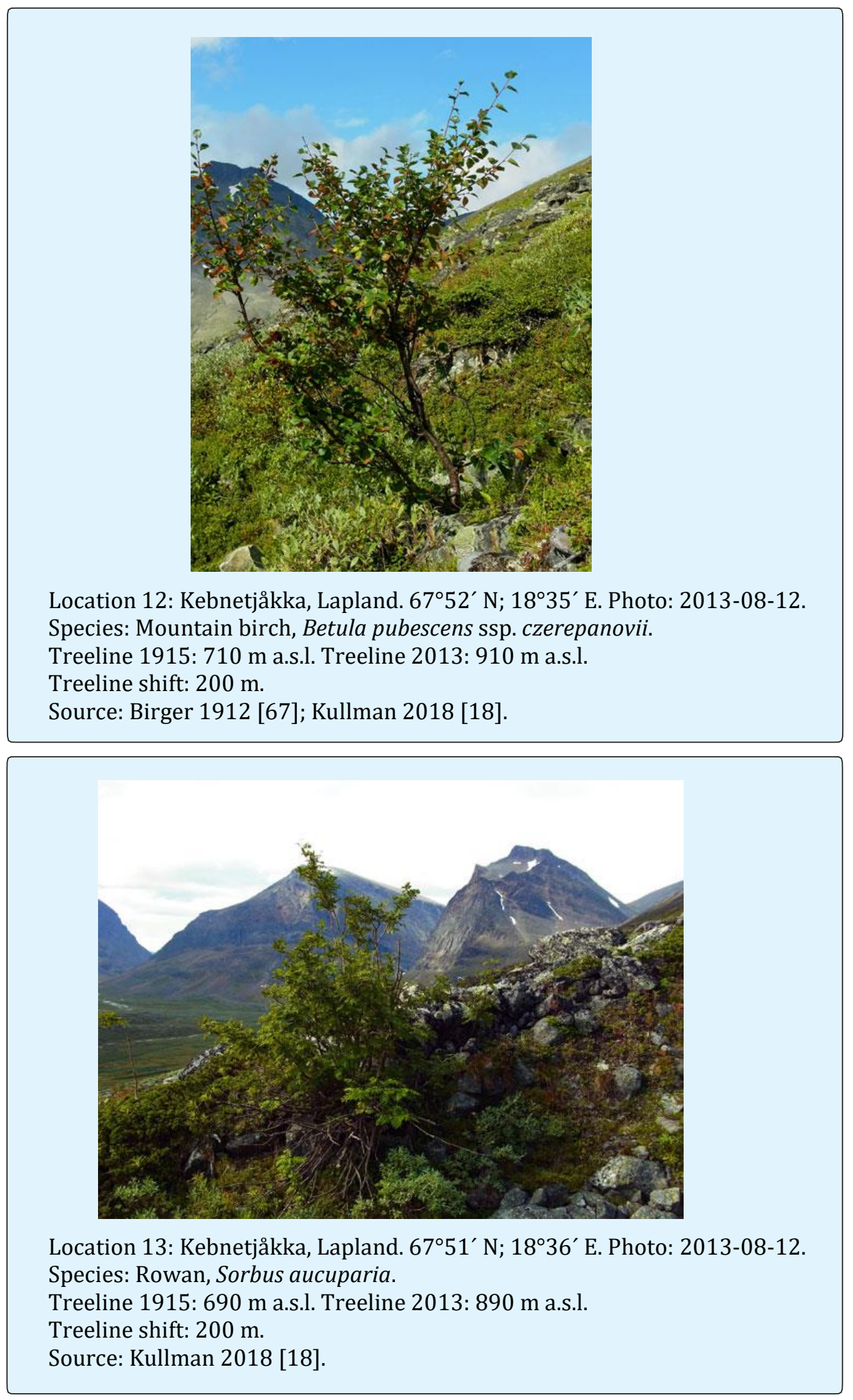

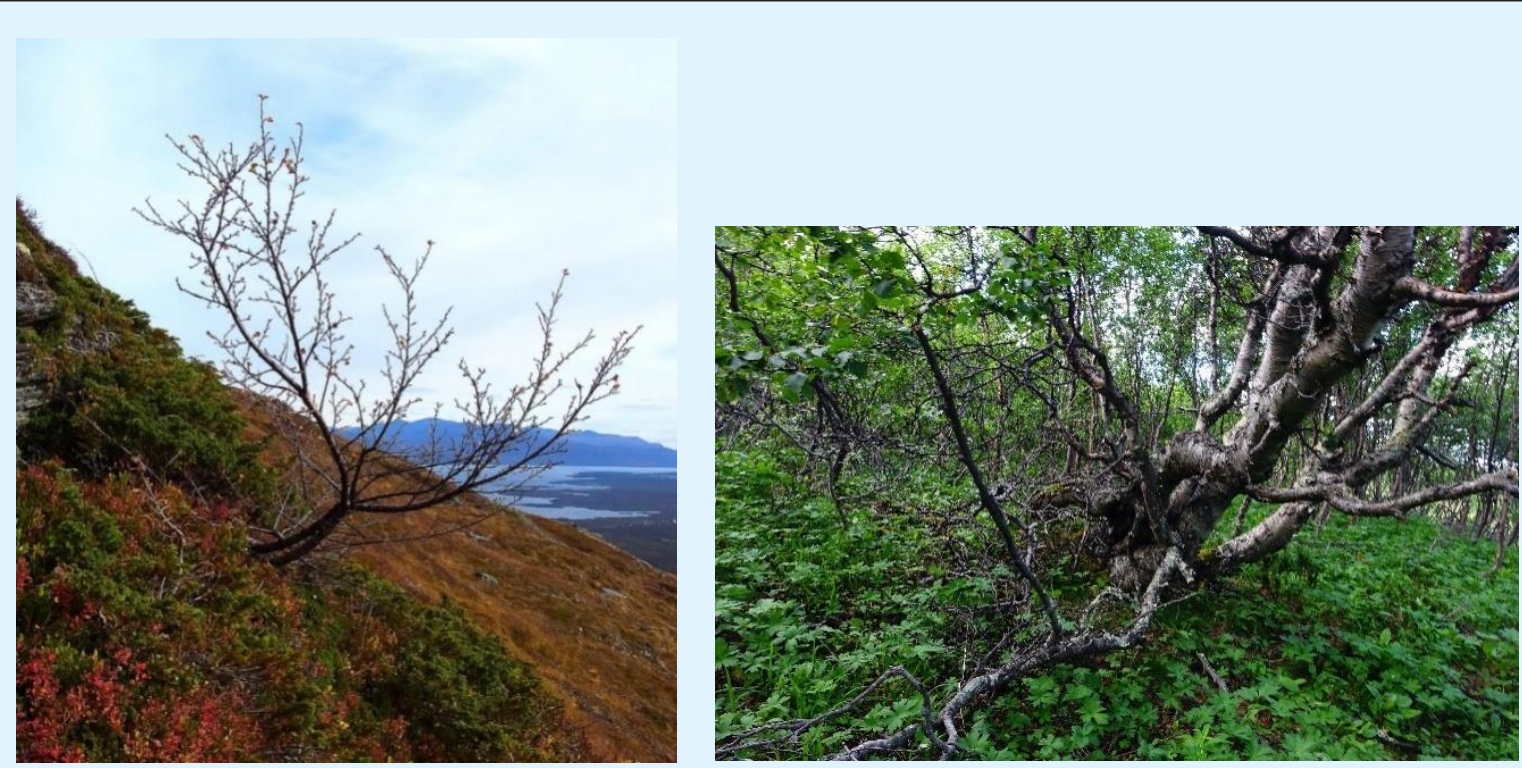

Location 14: Slåttatjåkka, Lapland. 68²3’ N; 18²2’ E. Left. Photo: 2013-09-14. Right. Tree representing the treeline position by the early 20th century. Photo: 2015-08-17.

Species: Mountain birch, Betula pubescens czerepanovii.

Treeline 1915: $660 \mathrm{~m}$ a.s.l. Treeline 2013: 890 m a.s.l.

Treeline shift: 230 m a.s.l.

Source: Kullman 2015b [11].

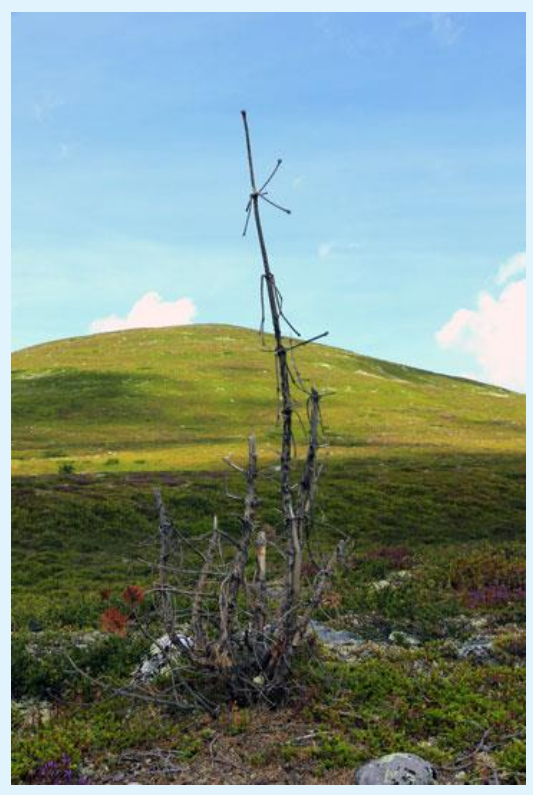

Figure 3: Failed trial to raise the pine treeline. This pine specimen nearly reached a height of $2 \mathrm{~m}$ before it died quite recently as a consequence of winter desiccation. The location is $15 \mathrm{~m}$ above the new treeline, which here advanced by 140 m since early 20th century [27]. Mt. Storvätteshågna (Dalarna), 990 m a.s.l. Photo: 2013-07-28. 


\section{Synthesis of results}

All studied species, irrespective of their different ecologies and regenerative strategies, displayed the same exceptionally large degree of maximum elevational advance. No obvious differences could be seen between species or between the southern and northern Swedish Scandes.

In most cases, the new and advanced treelines do not represent entirely isolated outposts, but are regularly succeeded below by scattered and young trees, representing an upslope advance sequence of trees, ending up with the present-day elevated treeline. Neighbouring sites on the same and adjacent slopes may display lower treelines, occasionally more or less unchanged in position over the past one hundred years.

Most specimens are quite small, relative to those representing the treeline position by the early 20th century. In some cases they are obviously in bad shape of vigor. Therefore, they are vulnerable to extirpation and one may question the endurance of the new and raised treeline $[71,72,40]$.

As a rule, the upper limit of closed tree stands, i.e. the elusive forest limit, of all concerned species, is located hundreds of vertical meters below the new treeline and has only occasionally encroached significantly on the alpine tundra. However, stand density within the upper forest and in the treeline ecotone has increased substantially during the past 100 years, in response to raised temperatures $[13,11,15]$.

Spruce, birch and rowan have achieved their treeline upshifts predominantly by means of accelerated height growth of stunted pre-existing individuals, which prevailed as clonally reproducing krummholz long before the onset of the modern warming phase, in the early 20th century $[73,62]$. Given new and warmer conditions they shifted to upright tree mode. Pine has almost exclusively responded by spread and establishment of quite newly seed-regenerated specimens.

\section{Discussion}

In a broad-scale regional perspective of the Swedish Scandes, treelines of prevalent boreal tree species (Betula pubescens ssp. czerepanovii, Picea abies, Pinus sylvestris, Sorbus aucuparia), have locally, during the past 100 years, shifted upslope by about $200 \mathrm{~m}$, with a maximum of 245 m. Worldwide, these large advances may represent genuine treeline rises, independent of prior human impact [74]. Species with quite different regeneration modes (vegetative versus sexual) have, "at the end of the day", responded to virtually the same extent, although with different paces [28]. This generic pattern sustain that the treeline phenomenon may be an expression of a general principle [35].

Previous studies in this specific region have shown that treeline with this large order of magnitude is not a spatially ubiquitous pattern between near-by sites over the past 100 years [28]. At most investigated sites in the Swedish mountain landscape, modern treeline ascent is of substantially smaller extent, obviously constrained by local site conditions, relating to geomorphology, wind exposure and snow cover characteristics. In particular, level and wind exposed slopes with little propensity for snow retention, display insignificant treeline rises (Figure 4), while more complex geomorphic terrain patterns and associated geoecological characteristics support the largest upshifts [3].

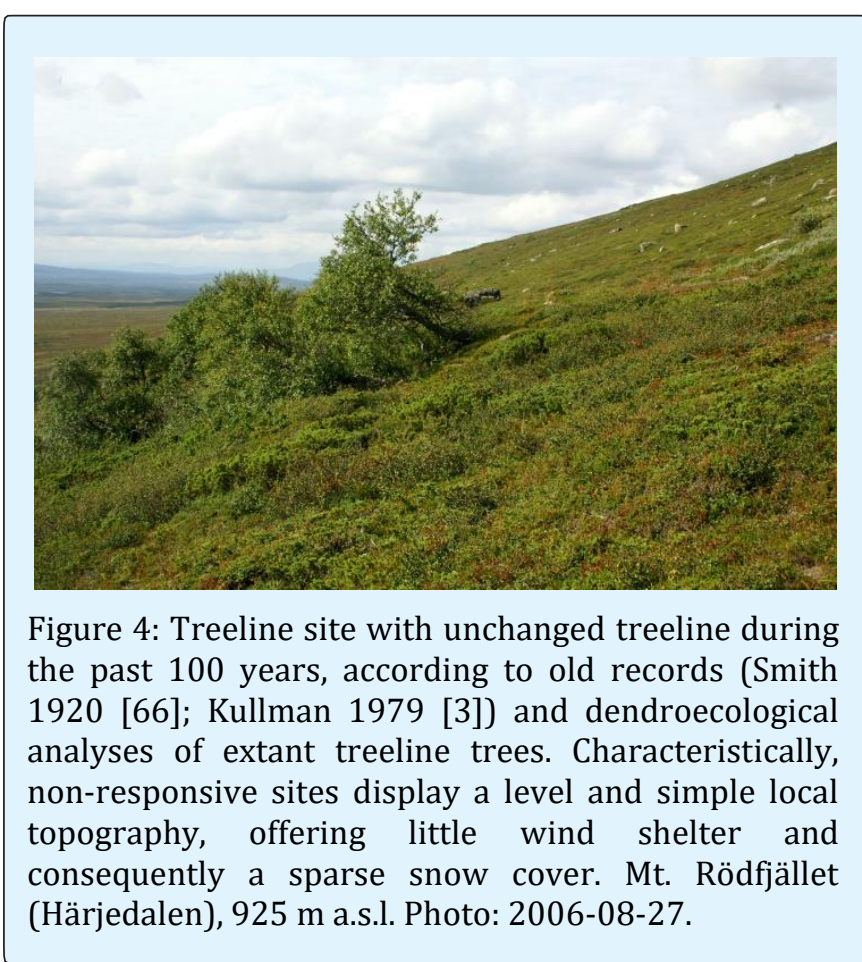

Local maximum treeline rise by $200-245 \mathrm{~m}$ is exceptional in a global perspective (but see Meshinev et al. 2000), and suggests that treelines and climate are in nearequilibrium, further supported by dead near-tree sized specimens, located just above the new treeline [17] 
(Figure 3). The contention of primary temperature control of recent treeline rise is based on the premise that summer temperature change by $0.6^{\circ} \mathrm{C}$ per $100 \mathrm{~m}$ altitude [61], which combines with recorded centennial warming by $1.6^{\circ} \mathrm{C}$ over the past 100 years (Figure 1 ).

Treeline upshifts by $200 \mathrm{~m}$ or somewhat more, along the entire south to north extent of the Swedish Scandes, suggest that the recent treeline history is virtually ubiquitous in a broad-scale geographical context. Also in a perspective of the entire Holocene, this common pattern seems to prevail [75]. Some prior studies, based on dendroecology and age structure analyses, maintain that modern treeline rise is not a general process along the entire Scandes $[59,60]$. This study falsifies that option.

Recent treeline rise by $200 \mathrm{~m}$ and more may be viewed in the perspective of the entire course of Holocene treeline change over more than 10000 years, as reconstructed by robust megafossil evidence $[43,17]$. Accordingly, the new and advanced treeline position may represent a treeline restored equally high as manifested about 7000 years ago, i.e. shortly after the Holocene thermal optimum, as inferred from different studies $[76,77]$. This pattern of major treeline advance portraits an unusually favourable climate during the past 100 years. However, this aspect needs to be viewed with caution, since long-term progression of the current climate trend and the stability of the new treeline remain uncertain, as evidenced from the present study.

Possibly, present and past treelines may not be fully compatible. The former being manifested by widely dispersed and tiny specimens in contrast to more stout representatives of the earlier. Thus, it is questionable whether these will leave any lasting imprint on the megafossil record. This implies that short-term warming episodes in the past, with treeline responses like that of the past 100 years, may have occurred. At least locally, that actually happened about 2000 and 1000 years ago [10].

Notably, extensive treeline rise, as evidenced in this study is not paralleled with significant upshift of the closed forest, as predicted by some studies [78].

\section{References}

1. Smithson P, Addison K, Atkinson K (2002) Fundamentals of the physical environment. Routledge, London.
2. Aas B (1969) Climatically raised birch lines in southeastern Norway 1918-1968. Norsk Geografisk Tidsskrift 23: 119-130.

3. Kullman L (1979) Change and stability in the altitude of the birch tree-limit in the southern Swedish Scandes. Acta Phytogeographica Suecica 65: 1-121.

4. Kullman L (1981) Recent tree-limit dynamics of Scots pine (Pinus sylvestris L.) in the southern Swedish Scandes. Wahlenbergia 8: 1-67.

5. Kullman L (1986) Recent tree-limit history of Picea abies in the southern Swedish Scandes. Canadian Journal of Forest Research 16(4): 761-771.

6. Kullman L (1998) Tree-limits and montane forests: Sensitive biomonitors of climate change and variability. Ambio 27(4): 312-321.

7. Kullman L (2007) Tree line population monitoring of Pinus sylvestris in the Swedish Scandes, 1973-2005: implications for tree line theory and climate change ecology. J Ecol 95(1): 41-52.

8. Kullman L (2010a) A richer, greener and smaller alpine world - review and projection of warminginduced plant cover change in the Swedish Scandes. Ambio 39(2): 159-169.

9. Kullman L (2010b) One century of treeline change and stability-experiences from the Swedish Scandes. Landscape Online 17: 1-31.

10. Kullman L (2015a) Higher-than-present Medieval pine (Pinus sylvestris) treeline along the Swedish Scandes. Landscape Online 42: 1-14.

11. Kullman L (2015b) Recent and past trees and climates at the arctic/alpine margin in Swedish Lapland: An Abisko case study review. J Biodiversity Manag \& Forest 4: 4.

12. Kullman L (2015c) Trädgräns i fjällen. Sammanställning och utvärdering av en metodstudie för klimatrelaterad miljöövervakning. Länsstyrelsen i Jämtlands län, Rapport Diarienummer 502-10912015.

13. Kullman L (2014a) Treeline (Pinus sylvestris) landscape evolution in the Swedish Scandes - a 40year demographic effort viewed in a broader 


\section{Journal of Ecology \& Natural Resources}

temporal context. Norwegian J Geography 68: 155167.

14. Kullman L (2014b) Trädgränsens förändring 1974 till 2013. Fotoserie från fjället Östra Barfredhågna i norra Dalarna. Länsstyrelsen i Dalarnas Län, Rapport 2014: 09.

15. Kullman L (2016a) Climate and primary birch (Betula pubescens ssp, czerepanovii) succession in the treeline ecotone in the Swedish Scandes. Int J Res Geography 2(2): 36-47.

16. Kullman L (2016b) Pine (Pinus sylvestris) penetration towards the head of the Handölan Valley - recent reversal of a long-term retrogressional trend - contrasting responses of tree- and forest line. Int J Environ Agricul Res 2(5): 163-172.

17. Kullman L (2017a) Pine (Pinus sylvestris) treeline performance in the southern Swedish Scandes since the early 20th century. Acta Phytogeographica Suecica 90: 1-46.

18. Kullman L (2018) Recent treeline shift in the Kebnekaise Mountains, northern Sweden - a climate change case. Int J Current Res 10(1): 63786-63792.

19. Kremenetski KV, Vaschalova T, Sulerzhitsky L (1999) Holocene vegetation history of the Khibiny Mountains: implications for the post-glacial expansion of spruce and alder on the Kola Peninsula, northwestern Russia. J Quaternary Sci 14(1): 29-43.

20. Meshinev T, Apostolova I, Koleva E (2000) Influence of warming on timberline rising: a case study of Pinus peuce Griseb. in Bulgaria. Phytocoenologia 30(3-4): 431-438.

21. Shiyatov SG (2003) Rates of change in the upper treeline ecotone in the Polar Ural Mountains. Pages News 11: 6-8.

22. Körner C, Paulsen J (2004) A world-wide study of high-altitude treeline temperatures. J Biogeogr 31(5): 713-732.

23. Lloyd AH (2005) Ecological histories from Alaskan tree lines provide insight into future change. Ecol 86(7): 1687-1695.

24. Holtmeier FK, Broll G (2005) Sensitivity and response of northern hemisphere altitudinal and polar treelines to environmental change at landscape and local scales. Global Ecol Biogeograp 14(5): 395-410.

25. Kapralov DS, Shiyatov SG, Moiseev PA, Fomin VV (2006) Change in composition, structure, and altitudinal distribution of low forests at the upper limit of their growth in the Northern Ural Mountains. Russian J Ecol 37(6): 367-372.

26. Danby RK, Hik DS (2007) Variability, contingency and rapid change in recent subarctic alpine tree line dynamics. J Ecol 95(2): 352-363.

27. Devi N, Hagedorn F, Moiseev P, Bugmann H, Shiyatov $\mathrm{S}$, et al. (2008) Expanding forests and changing growth forms of Siberian larch at the polar Urals treeline during the 20th century. Global Change Biol 14(7): 1581-1591.

28. Kullman L, Öberg L (2009) Post-Little Ice Age treeline rise and climate warming in the Swedish Scandes: a landscape ecological perspective. J Ecol 97(3): 415429.

29. Kullman L, Öberg L (2018) A one hundred-year study of the upper limit of tree growth (Terminus arboreus) in the Swedish Scandes - updated and illustrated change in an historical perspective. Int J Res Geography 4(2): 10-35.

30. Kharuk VI, Ranson KJ, Im ST, Dvinskaya ML (2009) Response of Pinus sibirica and Larix sibirica to climate change in southern Siberian alpine forest tundra. Scandinavian J Forest Res 24(2): 130-139.

31. Harsch MA, Hulme PE, McGlone MS, Duncan RP (2009) Are treelines advancing? A global metaanalysis of treeline response to climate warming. Ecology Letters 12(10): 1040-1049.

32. Elliott GP (2011) Influences of 20th-century warming at the upper tree line contingent on local-scale interactions: evidence from a latitudinal gradient in the Rocky Mountains, USA. Global Ecol Biogeography 20(1): 46-57.

33. Leonelli G, Pelfini M, Morra diCella U, Garavaglia V (2011) Climate warming and the recent treeline shift in the European Alps: the role of geomorphological factors in high-altitude sites. Ambio 40(3): 264-273.

34. Kirdyanov AV, Hagedorn F, Knorre AA, Fedotova EV, Vaganov EA, et al. (2012) 20th century tree-line 


\section{Journal of Ecology \& Natural Resources}

advance and vegetation changes along an altitudinal transect in the Putorana Mountains, northern Siberia. Boreas 41(1): 56-67.

35. Körner C (2012) Alpine treelines: functional ecology of the global high elevation tree limits. Springer Science \& Business Media.

36. Hofgaard A, Tømmervik H, Rees G, Hanssen F (2013) Latitudinal forest advance in northernmost Norway since the early 20th century. J Biogeogr 40(5): 938949.

37. Hagedorn F, Shiyatov SG, Mazepa VS, Nadezhda MD, Andrey AG, et al. (2014) Treeline advances along the Ural mountain range - driven by improved winter conditions. Global Change Biology 20(11): 3530 3543.

38. Gaire NP, Koirala M, Bhuju DR, Borgaonkar HP (2014) Treeline dynamics with climate change at the central Nepal Himalaya. Climate of the Past 10: 1277-1290.

39. Aakala T, Hari P, Dengel S, Newberry SL, Mizunuma T, et al. (2014) A prominent stepwise advance of the tree line in north-east Finland. J Ecol 102(6): 15821591.

40. Millar CI, Westfall RD, Delany DI, Flint LE (2015) Recruitment patterns and growth of high-elevation pines in the western Great Basin, USA. Canadian J Forest Res 45: 1299-1312.

41. Holtmeier FK, Broll G (2017) Treelines - approaches at different scales. Sustainability 9(5): 1-19.

42. Berger A (1988) Milankovitch theory and climate. Review Geophysics 26(4): 624-657.

43. Kullman L (2013) Ecological tree line history and palaeoclimate - review of megafossil evidence from the Swedish Scandes. Boreas 42(3): 555-567.

44. Kullman L, Öberg L (2015) New aspects of highmountain paleobiogeography: a synthesis of data from forefields of receding glaciers and ice patches in the Tärna and Kebnekaise Mountains, Swedish Lapland. Arctic 68(2): 141-152.

45. Holmlund P (2012) Glaciärer. Gnistrande smycken som ännu pryder våra svenska fjäll. Votum \& Gullers Förlag, Karlstad.
46. Hustich I (1979) Ecological concepts and biogeographical zonation in the north: the need for a generally accepted terminology. Holarctic Ecology 2(4): 208-217.

47. Holtmeier FK (2003) Mountain timberlines. Ecology, patchiness and dynamics. Kluwer, Dordrecht.

48. Schickhoff U, Bobrowski M, Böhner J, Bürzle B, Chaudhary RP, et al. (2015) Do Himalayan treelines respond to recent climate change? An evaluation of sensitivity indicators. Earth System Dynamics 6: 245265.

49. Kjällgren L, Kullman L (2002) Geographical patterns of tree-limits of Norway spruce and Scots pine in the southern Swedish Scandes. Norwegian J Geogr 56(4): 237-245.

50. Rannow S (2013) Do shifting forest limits in southwest Norway keep up with climate change? Scandinavian J Forest Res 28(6): 574-580.

51. Bryn A, Pothoff K (2018) Elevational treeline and forest line dynamics in Norwegisan mountain areas a review. Landscape Ecol 33(8): 1295-1245.

52. Kullman L (2005) Mountain Taiga of Sweden. In: Seppälä M (Ed.), The Physical Geography of Fennoscandia. Oxford University Press, Oxford.

53. Kullman L (2012) The alpine treeline ecotone in the southernmost Swedish Scandes - dynamism on different scales. In: Myster R (Ed.), Ecotones between forest and grassland. Springer, New York.

54. Moen J, Cairns DM, Lafon CW (2008) Factors structuring the treeline ecotone in Fennoscandia. Plant Ecol Divers 1(1): 77-87.

55. Guo Q, Taper M, Shoenberger M, Brandle J (2005) Spatial-temporal population dynamics across species range: from centre to margin. Oikos 108(1): 47-57.

56. Aitken SN, Yeaman S, Halliday JA, Wang T, CurtisMcLane S (2008) Adaptation, migration or extirpation: climate change outcomes for tree populations. Ecol App 1(1): 95-111.

57. Shackleton CM, Prins F (1992) Charcoal analysis and the "Principle of Least Effort". J Archaeol Sci 19(6): 631-637. 
58. Blüthgen J (1960) Der skandinavische Fjällbirkenwald als Landschaftsformation. Petermanns Geographische Mitteilungen 104(2/3): 119-144.

59. Dalen L, Hofgaard A (2005) Differential regional treeline dynamics in the Scandes. Arctic, Antarctic, and Alpine Research 37(3): 284-296.

60. Hofgaard A, Dalen L, Hytteborn H (2009) Tree recruitment above the treeline and potential for climate.driven treeline change. J Vegetation Sci 20(6): 1133-1144.

61. Laaksonen K (1976) The dependence of mean air temperature upon latitude and altitude in Fennoscandia. Ann Acad Sci Fenn A3 199: 1-19.

62. Öberg L, Kullman L (2012) Contrasting short-term performance of mountain birch (Betula pubescens ssp. czerepanovii) treeline along a latitudinal continentality-maritimity gradient in the southern Swedish Scandes. Fennia 190(1): 19-40.

63. Olofsson J, Oksanen L, Callaghan T, Hulme PE, Oksanen T, et al. (2009) Herbivores inhibits climatedriven shrub expansion in the tundra. Global Change Biology 15(11): 2681-2693.

64. Tenow 0 (1996) Hazards to a mountain birch forest Abisko in perspective. Ecol Bullet 45: 104-114.

65. Karlsson PS, Tenow O, Bylund H, Hoogesteger J, Weih M (2004) Determinants of mountain birch growth in situ: effects of temperature and herbivory. Ecography 27(5): 659-669.

66. Smith H (1920) Vegetationen och dess utvecklingshistoria i det centralsvenska högfjällområdet. Almqvist \& Wiksell, Uppsala.

67. Birger S (1912) Kebnekaisetraktens flora. Ett bidrag till kännedomen om floran i öfversta delen af Kalixälfvens dal. Svensk Botanisk Tidskrift 6(2): 195217.

68. Kullman L (1980) Trädslagsfördelning i nutid och sen historisk tid i översta Umeälvsdalen. Sveriges Skogsvårdsförbunds Tidskrift 78: 52-95.
69. Kullman L (1991) Pattern and process of present tree-limits in the Tärna region, southern Swedish Lapland. Fennia 169(1): 25-38.

70. Kullman L, Öberg L (2013) Melting glaciers and ice patches in Swedish Lapland provide new insights into the Holocene arboreal history. Geo Öko 33: 121-146.

71. Kullman L (2000) Tree-limit rise and recent warming: a geoecological case study from the Swedish Scandes. Norwegian J Geography 54(2): 49-59.

72. Mamet SD, Kershaw GP (2012) Subarctic and alpine treeline dynamics during the last 400 years in northwestern and central Canada. J Biogeography 39(5): 855-868.

73. Öberg L, Kullman L (2011) Ancient subalpine clonal spruces (Picea abies): sources of postglacial vegetation history in the Swedish Scandes. Arctic 64(2): 183-196.

74. Nagy L (2006) European high mountain (alpine) vegetation and its suitability for indicating climate change impacts. Biol Environ: Proceedings Royal Irish Academy 106B(3): 335-341.

75. Kullman L (2017b) Melting glaciers in the Swedish Scandes provide new insight into palaeotreeline performance. Int J Current Multidisciplinary Stud 3(3): 607-618.

76. Paus A (2013) Human impact, soil erosion, and vegetation response lags to climate change: challenges for the mid-Scandinavian pollen-based transfer-function temperature reconstructions. Vegeta History Archaeobotany 22(3): 269-284.

77. Luoto TP, Kaukolehto M, Weckström J, Korhola A, Väliranta M (2014) New evidence of warm early Holocene summers in subarctic Finland based on an enhanced regional chironomid-based temperature calibration model. Quaternary Research 81(1): 50-62.

78. Moen J, Aume K, Edenius L, Angerbjörn A (2004) Potential effects of climate change on treeline position in the Swedish mountains. Ecol Society 9(1): $1-11$. 